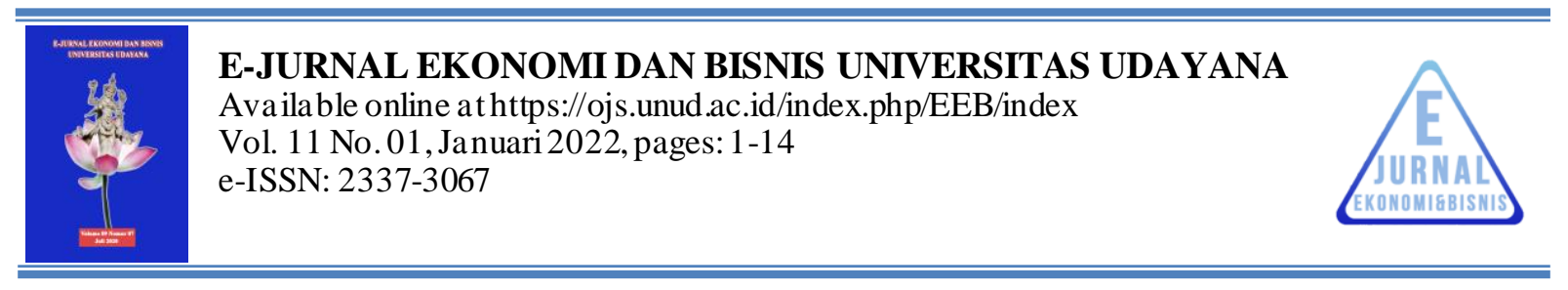

\title{
PENGARUH INVESTASI, PENGELUARAN PEMERINTAH, TENAGA KERJA TERHADAP PERTUMBUHAN EKONOMI DAN TINGKAT KEMISKINAN DI PROVINSI BALI
}

\author{
Lufi Supratiyoningsih $^{1}$ Ni Nyoman Yuliarmi ${ }^{2}$
}

Article history:

Submitted: 27 Juli 2021

Revised: 28 Agustus 2021

Accepted:2 September 2021

\section{Keywords:}

Investment;

Government Expenditure;

Employment;

Economic Growth;

Poverty Rate;

\section{Abstract}

This study aims 1) To analyze the effect of investment, government spending and labor on economic growth in Bali Province, 2) To analyze the effect of investment, government spending, labor and economic growth on povertylevelsin Bali Province, 3) To analyze the indirect effect of investment, government spending and labor on poverty levels through economic growth in Bali Province. The number of observations in this study was 63 observation points in the period 2013-2019 in 9 districts/cities of Bali Province using panel data. The data analysistechnique used in this research is path analysis. The results of this study indicate that 1) Investment has a positive and insignificant effect on economic growth, while government spending and labor have a positive and significant effect on economic growth;2) Government investment and spending have a ne gative and insignificant effect on the poverty level, while labor and economic growth have a negative and significant effect on the poverty level; 3 ) Investment doesnot indirectlyaffect the poverty rate through economic growth, while government spending and labor have an indirect effect on the poverty rate through economic growth.

\begin{abstract}
Abstrak
Penelitian ini bertujuan 1) Untuk menganalisis pengaruh investasi,
pengeluaran pemerintah dan tenaga kerja terhadap pertumbuhan ekonomidi
Provinsi Bali, 2) Untuk menganalisis pengaruh investa si, pengeluaran
pemerintah, tenaga kerja dan pertumbuhan ekonomi terhadap tingkat
kemiskinan di Provinsi Bali, 3) Untuk menganalisis pengaruh tidak langsung
investasi, pengeluaran pemerintah dan tena ga kerja terhadap tingkat
kemiskinan melalui pertumbuhan ekonomi di Provinsi Bali. Jumlah
pengamatan dalam penelitian ini dalah 63 titik pengamatan dalam rentang
waktu 2013-2019 di 9 kabupaten/kota Provinsi Bali dengan menggunakan
data panel. Teknik analisis data yang digunakan dalam penelitian ini adalah
analisis jalur. Ha sil penelitian ini menunjukkan bahwa 1) Investasi
berpengaruh positif dan tidak signifikan terhadap pertumbuhan ekonomi,
sedangkan pengeluaran pemerintah dan tenaga kerja berpengaruhpositif dan
signifikan terhadap pertumbuhan ekonomi; 2 ) Investasi dan pengeluaran
pemerintah berpengaruh negatif dan tidak signifikan terhadap tingkat
kemiskinan sedangkan tenaga kerja dan pertumbuhan ekonomi berpengaruh
negatif dan signifikan terhadap tingkat kemiskinan; 3) Investasi tidak
berpengaruh secara tidak langsung terhadap tingkat kemiskinan melalui
pertumbuhan ekonomi, sedangkan pengeluaran pemerintah dan tenaga kerja
berpengaruh secara tidak langsung terhadap tingkat kemiskinan melalui
pertumbuhan ekonomi.
Penelitian ini bertujuan 1) Untuk menganalisis pengaruh investasi, pengeluaran pemerintah dan tenaga kerja terhadap pertumbuhan ekonomi di Provinsi Bali, 2) Untuk menganalisis pengaruh investasi, pengeluaran pemerintah, tenaga kerja dan pertumbuhan ekonomi terhadap tingkat kemiskinan di ProvinsiBali, 3) Untuk menganalisis pengaruh tidaklangsung investasi, pengeluaran pemerintah dan tenaga kerja terhadap tingkat kemiskinan melalui pertumbuhan ekonomi di Provinsi Bali. Jumlah pengamatan da lam penelitian ini dalah 63 titik pengamatan dalam rentang waktu 2013-2019 di 9 kabupaten/kota Provinsi Bali dengan menggunakan da ta panel. Teknik analisis data yang digunakan dalam penelitia $n$ ini adalah analisis jalur. Hasil penelitian ini menunjukkan bahwa 1) Investasi berpengaruh positif dan tidak signifikan terhadap pertumbuhan ekonomi, sedangkan pengeluaran pemerintah dan tenaga kerja berpengaruh positif dan signifikan terhadap pertumbuhan ekonomi; 2) Investasi dan pengeluaran kemiskinan sedangkan tenaga kerja dan pertumbuhan ekonomi berpengaruh negatif dan signifikan terhadap tingkat kemiskinan; 3) Investasi tidak berpengaruh secara tidak langsung terhadap tingkat kemiskinan melalui pertumbuhan ekonomi.
\end{abstract}

Investasi;

Pengelua ran Pemerintah;

Tenaga Kerja;

Pertumbuhan Ekonomi;

Tingkat Kemiskinan;

\section{Koresponding:}

Fakulas Ekonomi dan Bisnis

Universitas Udayana, Bali, Indonesia

Email:

supratiyoningsih@gmail.com

Fakultas Ekonomid an Bisnis Universitas Udayana, Bali, Indonesia ${ }^{2}$

Email: nyuliarmi@unud.ac.id 


\section{PENDAHULUAN}

Pertumbuhan ekonomi digunakan sebagai indicator dalam melihat perkembangan ekonomi daerah. Indonesia sebagai negara berkembang, pencapaian pertumbuhan ekonomi diiringi dengan peningkatan jumlah penduduk dibawah garis kemiskinan (Jonnaidi, 2012). Purnama (2016) menyebutkan bahwa kemiskinan adalah permasalahan multidimensional sebab dalam mengatasinya tidak terbatas dalam hubungan sebab akibat, tetapi juga melibatkan preferensi, nilai, dan politik. Salah satu tujuan pembangunan adalah untuk mengentaskan kemiskinan dan melalui kemiskinan sebagai tolok ukur efektivitas kebijakan dan program pembangunan yang telah ditetapkan. Pembangunan daerah adalah proses pengelolaan sumber daya dan potensi daerah oleh pemerintah dan penduduknya serta bekerjasama dengan pihak swasta untuk membuka lapangan pekerjaan baru dan merangsang pertumbuhan ekonomi daerah tersebut (Pratama dan Utama, 2019).

Provinsi Bali memiliki sembilan kabupaten/kota dengan ciri khas wilayah masing-masing. Bali memiliki laju pertumbuhan ekonomi yang tinggi namun ternyata tidak dapat menjamin adanya pemertaan pembangunan dan kesejahteraan penduduk, terlihat dari persentase penduduk miskin yang cukup banyak. Dewi (2013) menyebutkan bahwa terjadinya ketimpangan pendapatan antar kabupaten/kota di Bali harus diatasi sebagai upaya peningkatan perekonomian. Pembangunan ekonomi tidak hanya sebagai indicator pertumbuhan ekonomi, namun juga mengindikasikan aktivitas ekonomi pada periode tertentu sebagai pendapatan masyarakat. Berdasarkan data dari BPS Provinsi Bali tahun 2020, diketahui bahwa perkembangan pertumbuhan ekonomi menurut kabupaten/kota di Provinsi Bali mengalami fluktuasi dari tahun 2013-2019. Kabupaten Badung memiliki jumlah PDRB perkapita paling besar diantara kabupaten dan kota di Provinsi Bali. mencapai 93.585 ribu rupiah perkapita, sedangkan 8 kabupaten/kota lainnya memiliki jumlah PDRB perkapita masih dibawah Kabupataen Badung. Hal ini menunjukkan adanya ketidakmerataan pendapatan antar di Provinsi Bali

Todaro (2000) mengemukakan bahwa pendapatan perkapita menunjukkan keberhasilan pemerintah daerah dalam pembangunan, dan mengetahuai besaran serta akibat yang ditimbulkan dari peningkatan tersebut. Semakin tinggi pendapatan perkapita yang diterima maka semakin tinggi pula daya beli yang dilakukan, kemampuan yang bertambah ini menandakan masyarakat sudah mampu memenuhi kebutuhan hidupnya sehingga dapat mengurangi kemiskinan yang terjadi. Peetumbuhan ekonomi memegang peranan penting dalam mengentaskan kemiskinan. Berdasarkan teori Trickle Down Effect menyebutkan adanya aliran menetas ke bawah, dari kelompok kaya ke kelompok miskin melalui fungsi-fungsi dalam ekonomi (Perry et al., 2007). Berbagai program telah dilaksanakan dengan tujuan untuk mengentaskan kemiskinan, namun jumlah penduduk miskin tidak dapat dihapuskan secara keseluruhan. Hal ini ditunjukkan dari data bahwa jumlah masyarakat yang masih tergolong kurang mampu tetap ada di setiap kabupaten/kota di Provinsi Bali (Yuliarmi, 2014).

Penurunan tingkat kemiskinan di Provinsi Bali tidak terlepas dari upaya pengentasan kemiskinan oleh pemerintah pusat maupun daerah dalam bentuk program-program pro-poor. Namun demikian, masih eksisnya permasalahan kemiskinan di Bali mencerminkan masih diperlukannya formulasi kebijakan yang lebih efektif sehingga mampu mengatasi permasalahan kemiskinan secara menyeluruh (Dariwardani, 2014). Upaya pengentasan kemiskinan juga dilakukan dengan melihat beberapa faktor yang menjadi penyebab turunnya tingkat kemiskinan yaitu pertumbuhan ekonomi, investasi, tenaga kerja dan pengeluaran pemerintah yang memiliki hubungan yang positif terhadap peningkatan kesejahteraan masyarakat.

Tingkat kemiskinan pada kabupaten/kota di Provinsi Bali ditentukan oleh adanya investasi. Hal ini sejalan dengan penelitian yang dilakukan Almfraji, et al (2014) menemukan hasil bahwa investasi asing (PMA) berpengaruh signifikan terhadap pertumbuhan ekonomi. Hal ini juga didukung oleh penelitian Samuel Adams (2009) yang menganalisis dampak dari investasi asing dan investasi domestik

Pengaruh Investasi, Pengeluaran Pemerintah, Tenaga Kerja Terhadap Pertumbuhan Ekonomi dan Tingkat

Kemiskinan di ProvinsiBali,

Lufi Supratiyoningsih dan Ni Nyoman Yuliarmi 
terhadap pertumbuhan ekonomi di Sub-Saharan Africa selama 1990-2003 bahwa investasi domestik berpengaruh signifikan pada pertumbuhan ekonomi. Menurut arsyad-Domar, bahwa investasi merupakan kunci utama dalam pertumbuhan ekonomi suatu daerah. Semakin meningkatnya pertumbuhan ekonomi pada suatu daerah, maka semakin tinggi pula investasi suatu daerah, semakin tingginya investasi, pengangguran akan menurun, apabila tingkat pengangguran rendah maka akan berbanding lurus terhadap tingkat kemiskinan (Arsyad, 2010).

Dalam teori Keynesian, pengeluaran pemerintah memiliki hubungan dengan pertumbuhan ekonomi, dimana ketika terjadi peningkatan pengeluaran pemerintah maka akan berdampak pada kenaikan pertumbuhan ekonomi dilihat dari pendapatan dan tingkat output (Mankiw, 2003). Upaya penanggulangan kemiskinan tidak terlepas dari jumlah pengeluaran pemerintah daerah. Pengeluaran pemerintah yang terus meningkat setiap tahun diharpkan dapat meningkatkan kesejahteraan masyarakat dan menurunkan angka kemiskinan. Pengeluaran pemerintah juga tidak hanya melihat jumlahnya saja tapi juga melihat ketepatan sasaran dalam pengeluaran pemerintah (De Fina, 2002).

Tenaga kerja merupakan faktor pendorong pertumbuhan ekonomi. Semakin banyak tenaga kerja berkualitas yang tersedia, maka output yang dihasilkan akan semakin banyak, sehingga akan mempengaruhi pendapatan perkapita. Ketika pendapatan perkapita naik maka pertumbuhan ekonomi juga akan meningkat (Risnawati dkk., 2019). Meningkatnya penyerapan tenaga kerja sebagai modal untuk pembangunan daerah akan menjadi jalan untuk menurunkan tingkat kemiskinan yang terjadi (Pascual, 2006). Ada dua tantangan besar di lingkungan domestik dan internasional yang sulit diprediksi, yaitu penciptaan lapangan kerja yang lebih baik dan lebih aman serta peningkatan produktivitas demi memperbaiki standar hidup dan mengurangi kemiskinan (Sarah \& Chris, 2017). Berdasarkan hal tersebut pemerintah daerah terlebih dahulu meningkatkan pertumbuhan ekonomi yang kemudian didistribusi atau memberikan dampak terhadap daerah-daerah dalam tingkat kesejahtraan dan menurunkan tingkat kemiskinan yang terdapat di daerah (Balisacan et al., 2003).

Ishengoma \& Robert (2006) menyebutkan bahwa tingkat pertumbuhan ekonomi yang negatif akan meningkatkan pengangguran dan angka kemiskinan. Maka dari itu, semakin tinggi pertumbuhan ekonomi, maka akan semakin tercapai penurunan kemiskinan (Bibi, 2006). Upaya penanggulangan kemiskinan di Provinsi Bali telah dilaksanakan dengan berbagai program dan oleh berbagai sektor dengan kriteria sasaran yang berbeda-beda. Dengan demikian pelaksanaan paket kegiatannya berjalan mengedepankan konsep sektoral, sehingga terintegrasi, bersinergi dan terkoordinasi. Ada tiga strategi utama yang harus dilakukan dalam menanggulangi masalah kemiskinan yaitu bantuan sosial seperti memberikan akses bagi rumah tangga miskin untuk mendapatkan pelayanan baik itu pendidikan, kesehatan, air bersih dan kebutuhan gizi, melakukan pemberdayaan kepada masyarakat miskin agar mampu meningkatkan taraf hidupnya menjadi lebih baik lagi dan yang terakhir adalah memberikan bantuan berupa kredit bagi usaha ekonomi mikro dan kecil (Putra \& Budhi, 2015).

Teori Harrod-Domar menyatakan bahwa dalam mewujudkan pertumbuhan ekonomi yang tinggi diperlukan pembentukan modal (investasi), dengan investasi yang tinggi perekonomiaan akan kuat (steady growth). Investasi akan meningkatkan produktivitas barang dan jasa (Sukirno, 2011). Investasi berpengaruh positif dan signifikan terhadap pertumbuhan ekonomi, berdasarkan hasil dari penelitian Pratama \& Suyana (2019) investasi dapat menjadi tolok ukur bagi keberhasilan dan keberlanjutan pembangunan di masa depan karena dapat menyerap tenaga kerja, sehingga dapat membuka kesempatan kerja baru bagi masyarakat yang pada gilirannya akan berdampak terhadap peningkatan pendapatan masyarakat. Sebagai instrumen kebijakan yang utama bagi pemerintah daerah, Anggaran Daerah atau Anggaran Pendapatan dan Belanja Daerah (APBD) menduduki posisi sentral (central position) dalam upaya pengembangan kapabilitas dan efektivitas pemerintahan daerah. Hasil penelitian yang dilakukan oleh Putra (2017) dimana pengeluaran pemerintah berpengaruh positif

Pengaruh Investasi, Pengeluaran Pemerintah, Tenaga Kerja Terhadap Pertumbuhan Ekonomi dan Tingkat 
terhadap pertumbuhan ekonomi. Tujuan dari pengeluaran pemerintah yang cukup besar adalah pembangunan infrastruktur karena dengan adanya infrastruktur yang memadai dan semakin berkualitas memang sangat diperlukan untuk memacu laju pertumbuhan ekonomi dan dapat menjamin tercapainya kesejahteraan bagi seluruh lapisan masyarakat secara lebih merata.

Menurut teori Solow-Swan, pertumbuhan ekonomi tergantung pada pertumbuhan penyediaan faktor-faktor produksi (penduduk, tenaga kerja dan akumulasi modal) dan kemajuan teknologi. Pertumbuhan penduduk dan pertumbuhan tenaga kerja secara tradisional dianggap sebagai salah satu faktor positif yang memacu pertumbuhan ekonomi. Penelitian yang dilakukan Prasetyawan dkk., (2017) mendapatkan bahwa tenaga kerja berpengaruh negatif terhadap tingkat kemiskinan, artinya semakin tinggi tenaga kerja maka tingkat kemiskinan akan semakin menurun.

Menurut teori Nurkse kemiskinan bertumpu pada teori lingkaran setan (vicious circle of proverty). Rendahnya investasi akan berakibat pada keterbelakangan dan seterusnya. Proses melingkar ini menyebabkan masyarakat miskin sulit keluar dari kemiskinannya jika tidak ada intervensi dari luar. Pertumbuhan ekonomi akan menciptakan investasi, membuka lapangan kerja, menyerap angkatan kerja, yang pada gilirannya akan menurunkan tingkat kemiskinan. Berdasarkan penelitian Jonaidi (2012) menyatakan bahwa kemiskinan berkolesai negatif terhadap pertumbuhan ekonomi. Pertumbuhan ekonomi yang tinggi akan mensejahterahkan masyarakat, dimana antara masyarakat berpenghasilan tinggi dan berpenghasilan rendah sama-sama dapat menikmati dari hasil dari tingginya pertumbuhan ekonomi.

Berdasarkan penjelasan rumusan masalah, dan penelitian-penelitian sebelumnya, dapat dirumuskan beberapa hipotesis penelitian sebagai berikut: $\mathrm{H}_{1}$ : Investasi, pengeluaran pemerintah dan tenaga kerja secara langsung berpengaruh positif terhadap pertumbuhan ekonomi kabupaten/kota Provinsi Bali, $\mathrm{H}_{2}$ : Investasi, pengeluaran pemerintah, tenaga kerja dan pertumbuhan ekonomi secara langsung berpengaruh negatif terhadap tingkat kemiskinan di kabupaten/kota Provinsi Bali, H3 : Investasi, pengeluaran pemerintah dan tenaga kerja secara tidak langsung berpengaruh terhadap tingkat kemiskinan melalui pertumbuhan ekonomi di kabupaten/kota Provinsi Bali

\section{METODE PENELITIAN}

Penelitian ini mengungkapkan positif dan negatif suatu pengaruh atau hubungan variabel yang ditanyakan dalam angka - angka. Penelitian ini dilakukan untuk menganalisis pengaruh investasi, pengeluaran pemerintah, tenaga kerja terhadap pertumbuhan ekonomi dan tingkat kemiskinan di kabupaten/kota Provinsi Bali. Lokasi penelitian dilakukan di sembilan kabupaten/kota Provinsi Bali dengan menggunakan data yang dikeluarkan dan dipublikasikan oleh BPS dan instansi yang berkaitan dengan objek penelitian. Objek penelitian ini adalah investasi, pengeluaran pemerintah, tenaga kerja, pertumbuhan ekonomi dan tingkat kemiskinan di kabupaten/kota Provinsi Bali.

Jumlah pengamatan dalam penelitian ini yaitu 9 (kabupaten) $\mathrm{x}$ (tahun) $=63$ pengamatan. Jenis data yang digunakan dalam penelitian ini adalah data kuantitatif. Sumber data pada penelitian ini menggunakan data sekunder, diperoleh dari Badan Pusat Statistik Provinsi Bali dan instansi lainnya. Dalam penelitian ini, pengumpulan data dilakukan dengan cara mengamati dan mencatat dokumendokumen yang di dapat dari instansi terkait seperti data investasi, tenaga kerja dan tingkat kemiskinan didapat dari situs resmi Badan Pusat Statistik Provinsi Bali dan data pengeluaran pemerintah didapat dari situs resmi Direktorat Jenderal Perimbangan Keuangan (DJPK). Teknik analisis data yang digunakan dalam penelitian ini adalah analisis jalur. Analisis ini digunakan untuk mengetahui hubungan langsung variabel independen terhadap variabel dependen dan hubungan yang tidak langsung melalui variabel intervening. Pengaruh langsung terjadi jika satu variabel mempengaruhi variabel lainnya tanpa

Pengaruh Investasi, Pengeluaran Pemerintah, Tenaga Kerja Terhadap Pertumbuhan Ekonomi dan Tingkat 
ada variabel lainnya yang memediasi (intervening) hubungan kedua variabel tersebut. Hubungan tidak langsung adalah jika ada variabel lain yang memediasi hubungan kedua variabel tersebut (Utama, 2016).

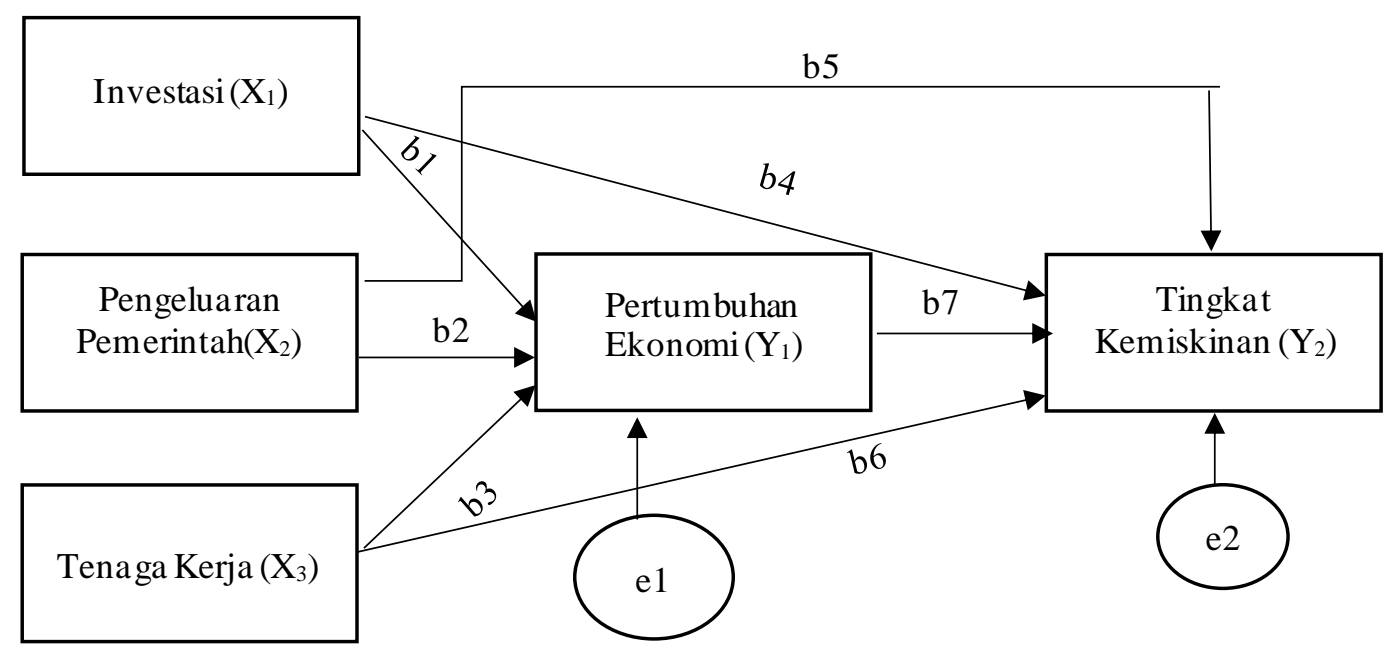

Gambar 1.

Kerangka Konseptual

\section{HASIL DAN PEMBAHASAN}

Tabel 1.

Hasil Analisis Statistik Deskriptif

\begin{tabular}{lrrrrr}
\hline & \multicolumn{5}{c}{ Descriptive Statistics } \\
& N & \multicolumn{1}{c}{ Minimum } & \multicolumn{1}{c}{ Maximum } & \multicolumn{1}{c}{ Mean } & \multicolumn{1}{c}{ Std. Deviation } \\
\hline Investasi & 63 & 312.00 & 1572880.00 & 180679.4286 & 284781.42831 \\
Pengeluaran & 63 & 14806.00 & 665550.00 & 193114.5238 & 139070.57438 \\
Pemerintah & 63 & 99416.00 & 516642.00 & 260484.4286 & 113989.46572 \\
Tenaga Kerja & 63 & 17179.00 & 93585.00 & 43070.8889 & 15334.20972 \\
Pertumbuhan & 63 & 178.00 & 744.00 & 483.9524 & 164.04911 \\
Ekonomi & 63 & & & & \\
Kemiskinan & & & & & \\
Valid N (listwise) & 6 Sumber: Datadiolah, 2021 & &
\end{tabular}

Berdasarkan Tabel 1 dapat dijelaskan bahwa banyaknya data yang digunakan sejumlah 63 data. Variabel investasi memiliki nilai minimum sebesar 3,12 miliar rupiah dan nilai maximum sebesar 1.572,880 miliar rupiah hal ini menunjukkan data investasi di seluruh kabupaten/kota Provinsi Bali. Dengan rata-rata sebesar 1.806,79 miliar rupiah dan standar deviasinya sebesar 2.847,81 miliar rupiah, maka mengandung makna bahwa nilai rata-rata merupakan bukan representasi yang baik dalam menggambarkan nilai investasi. Variabel pengeluaran pemerintah memiliki nilai minimum sebesar 148.06 miliar rupiah dan nilai maximum sebesar 6.655,50 miliar rupiah hal ini menunjukkan data pengeluaran pemerintah di seluruh nilai kabupaten/kota Provinsi Bali. Dengan rata-rata sebesar 1.931,14 miliar rupiah dan standar deviasinya sebesar 1.390,70 miliar rupiah. Nilai rata-rata yang lebih besar dibandingkan data standar deviasi mengandung makna bahwa nilai rata-rata merupakan representasi yang baik dalam menggambarkan nilai pengeluaran pemerintah. Variabel tenaga kerja memiliki nilai

Pengaruh Investasi, Pengeluaran Pemerintah, Tenaga Kerja Terhadap Pertumbuhan Ekonomi dan Tingkat Kemiskinan di Provinsi Bali, 
minimum sebesar 99.416 ribu orang dan nilai maximum sebesar 516.642 ribu orang menunjukkan data tenaga kerja di seluruh kabupaten/kota Provinsi Bali. Dengan rata-rata sebesar 260.484 ribu orang dan standar deviasinya sebesar 113.989 ribu orang. Nilai rata-rata yang lebih besar dibandingkan data standar deviasi mengandung makna bahwa nilai rata-rata merupakan representasi yang baik dalam menggambarkan nilai tenaga kerja

Variabel pertumbuhan ekonomi memiliki nilai minimum sebesar 17.179 ribu rupiah perkapita, nilai maximum sebesar 93.585 ribu rupiah perkapita menunjukkan seluruh data pertumbuhan ekonomi di kabupaten/kota Provinsi Bali. Dengan rata-rata sebesar 43.070 ribu rupiah perkapita dan standar deviasinya sebesar 15.334 ribu rupiah perkapita. Nilai rata-rata lebih besar dibandingkan dengan nilai standar deviasi memiliki makna bahwa nilai rata-rata mewakili dengan baik data pertumbuhan ekonomi secara keseluruhan. Variabel tingkat kemiskinan memiliki nilai minimum sebesar 1.78 persen dan nilai maximum sebesar 7.44 persen hal ini menunjukkan seluruh data tingkat kemiskinan di kabupaten/kota Provinsi Bali. Dengan rata-rata sebesar 4.83 persen dan standar deviasinya sebesar 1.64 persen. Nilai rata-rata lebih besar dibandingkan nilai standar deviasi memiliki makna bahwa nilai rata-rata mewakili dengan baik data tingkat kemiskinan secara keseluruhan

Tabel 2.

Hasil Uji Persamaan I

Coefficients $^{\mathrm{a}}$

\begin{tabular}{|c|c|c|c|c|c|}
\hline \multirow{2}{*}{ Model } & \multicolumn{2}{|c|}{ Unstandardized Coefficients } & \multirow{2}{*}{$\frac{\text { Standardized Coefficients }}{\text { Beta }}$} & \multirow{2}{*}{$\mathrm{t}$} & \multirow{2}{*}{ Sig. } \\
\hline & $\mathrm{B}$ & Std.Error & & & \\
\hline (Constant) & 22393.185 & 4036.997 & & 5.547 & .000 \\
\hline Investasi & .010 & .006 & .180 & 1.631 & .108 \\
\hline $\begin{array}{l}\text { Pengeluaran } \\
\text { Pemerintah }\end{array}$ & .047 & .011 & .428 & 4.188 & .000 \\
\hline Tenaga Kerja & .038 & .015 & .280 & 2.507 & .015 \\
\hline
\end{tabular}

a.Dependent Variable: Pertumbuhan Ekonomi

Sumber: Data diolah, 2021

Berdasarkan hasil pengujian persamaan I pada tabel 2, investasi dengan nilai Standardized Coefficients Beta sebesar 0,180 dengan sig 0,108>0,05 menunjukkan bahwa investasi tidak berpengaruh signifikan terhadap pertumbuhan ekonomi. Pengeluaran pemerintah dengan nilai Standardized Coefficients Beta sebesar 0,428 dengan sig 0,000 $<0,05$ menunjukkan bahwa pengeluaran pemerintah berpengaruh positif dan signifikan terhadap pertumbuhan ekonomi, sedangkan tenaga kerja dengan nilai Standardized Coefficients Beta sebesar 0,280 dengan sig 0,015 <0,05 menunjukkan bahwa tenaga kerja memiliki pengaruh positif dan signifikan terhadap pertumbuhan ekonomi.

Tabel 3.

Hasil Uji Persamaan II

Coefficients $^{a}$

\begin{tabular}{|c|c|c|c|c|c|}
\hline \multirow{2}{*}{ Model } & \multicolumn{2}{|c|}{ Unstandardized Coefficients } & \multirow{2}{*}{$\frac{\text { Standardized Coefficients }}{\text { Beta }}$} & \multirow{2}{*}{$\mathrm{t}$} & \multirow{2}{*}{ Sig. } \\
\hline & $\mathrm{B}$ & Std.Error & & & \\
\hline (Constant) & 854.548 & 43.103 & & 19.826 & .000 \\
\hline Investasi & $-5.975 \mathrm{E}-5$ & .000 & -.104 & -1.137 & .260 \\
\hline $\begin{array}{l}\text { Pengeluaran } \\
\text { Pemerintah }\end{array}$ & $-9.644 \mathrm{E}-5$ & .000 & -.082 & -.869 & .389 \\
\hline Tenaga Kerja & -.001 & .000 & -.406 & -4.269 & .000 \\
\hline $\begin{array}{l}\text { Pertumbuhan } \\
\text { Ekonomi }\end{array}$ & -.004 & .001 & -.410 & -3.892 & .000 \\
\hline
\end{tabular}

a. Dependent Variable: Kemiskinan

Sumber: Da ta diolah, 2021

Pengaruh Investasi, Pengeluaran Pemerintah, Tenaga Kerja Terhadap Pertumbuhan Ekonomi dan Tingkat 
Berdasarkan hasil pengujian persamaan II pada tabel 3, investasi dengan nilai Standardized Coefficients Beta sebesar -0,104 dengan sig 0,260 > 0,05 menunjukkan bahwa investasi tidak berpengaruh signifikan terhadap tingkat kemiskinan. Pengeluaran pemerintah dengan nilai Standardized Coefficients Beta sebesar -0,082 dengan sig 0,389>0,05 menunjukkan bahwa pengeluaran pemerintah tidak berpengaruh signifikan terhadap tingkat kemiskinan. Tenaga kerja dengan nilai Standardized Coefficients Beta sebesar -0,406 dengan sig 0,000 < 0,05 menunjukkan bahwa tenaga kerja berpengaruh negatif dan signifikan terhadap tingkat kemiskinan sedangkan pertumbuhan ekonomi dengan nilai Standardized Coefficients Beta sebesar -0,410 dengan sig 0,000 $<0,05$ menunjukkan bahwa pertumbuhan ekonomi berpengaruh negatif dan signifikan terhadap tingkat kemiskinan.

Tabel 4.

Ringkasan Koefisien Jalur dan Signifikansi Hubungan Antar Variabel

\begin{tabular}{cccccc}
\hline Regresi & $\begin{array}{c}\text { Koef. Regresi } \\
\text { Standar }\end{array}$ & Standar Error & t-hitung & p-value & Keterangan \\
\hline $\mathrm{X} 1 \rightarrow \mathrm{Y} 1$ & 0,180 & 0,006 & 1,631 & 0,108 & Tidak Signifikan \\
$\mathrm{X} 2 \rightarrow \mathrm{Y} 1$ & 0,428 & 0,011 & 4,188 & 0,000 & Signifikan \\
$\mathrm{X} 3 \rightarrow \mathrm{Y} 1$ & 0,280 & 0,015 & 2,507 & 0,015 & Signifikan \\
$\mathrm{X} 1 \rightarrow \mathrm{Y} 2$ & $-0,104$ & 0,000 & $-1,137$ & 0,260 & Tidak Signifikan \\
$\mathrm{X} 2 \rightarrow \mathrm{Y} 2$ & $-0,082$ & 0,000 & $-0,869$ & 0,389 & Tidak Signifikan \\
$\mathrm{X} 3 \rightarrow \mathrm{Y} 2$ & $-0,406$ & 0,000 & $-4,269$ & 0,000 & Signifikan \\
$\mathrm{Y} 1 \rightarrow \mathrm{Y} 2$ & $-0,410$ & 0,001 & $-3,892$ & 0,000 & Signifikan \\
\hline
\end{tabular}

Sumber: Da ta diolah, 2021

Berdasarkan hasil perhitungan nilai determinasi total sebesar 0,792 mempunyai arti bahwa sebesar 79,2\% variasi tingkat kemiskinan dipengaruhi oleh investasi, pengeluaran pemerintah, tenaga kerja dan pertumbuhan ekonomi, sedangkan sisanya yaitu 20,8\% persen dijelaskan oleh variabel lain yang tidak terdapat dalam model.

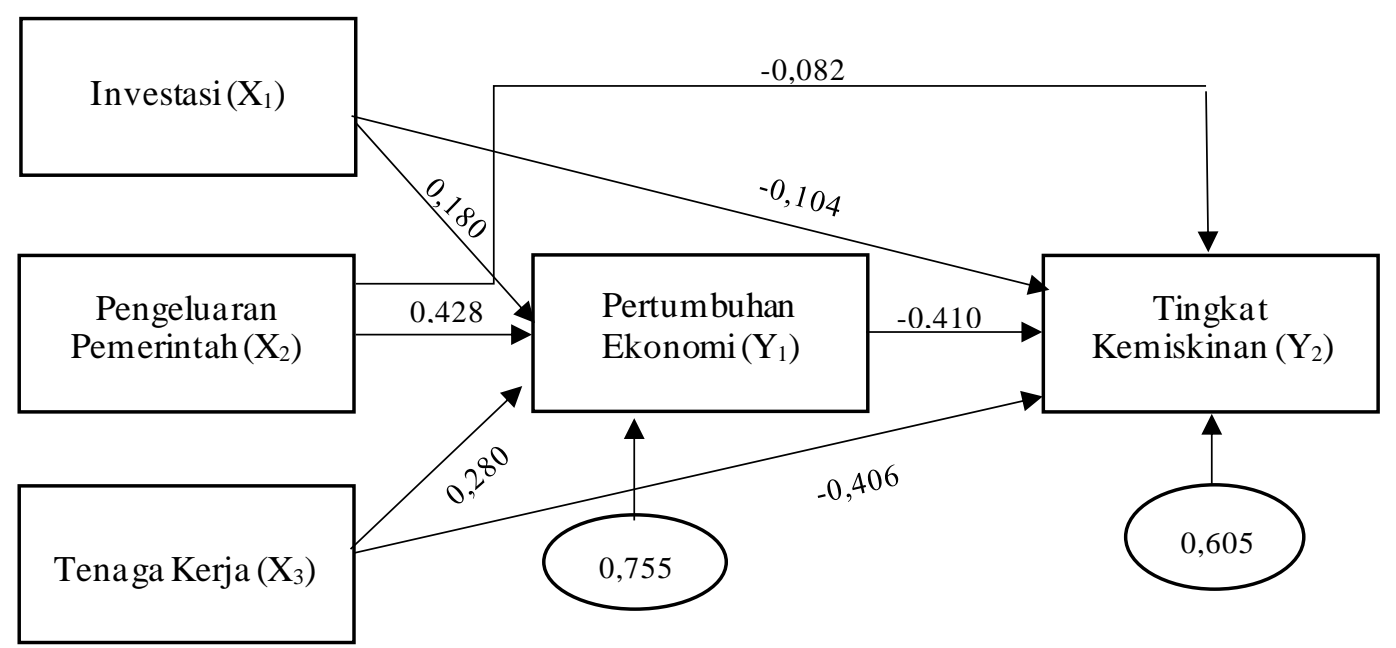

Sumber: Da ta diolah, 2021

Gambar 2.

Diagram Hasil Analisis Jalur

Pengaruh Investasi, Pengeluaran Pemerintah, Tenaga Kerja Terhadap Pertumbuhan Ekonomi dan Tingkat Kemiskinan di Provinsi Bali, 
Tabel 5.

Hasil Pengaruh Langsung, Pengaruh Tidak Langsung dan Pengaruh Total Variabel Investasi, Pengeluaran Pemerintah, Tenaga Kerja dan Pertumbuhan Ekonomi Terhadap Tingkat Kemiskinan

\begin{tabular}{cccc}
\hline Hubungan Variabel & Langsung & Tidak Langsung Melalui $\mathrm{Y}_{1}$ & TOTAL \\
\hline $\mathrm{X} \longrightarrow \mathrm{Y} 1$ & 0,180 & & 0,180 \\
$\mathrm{X} 1 \rightarrow \mathrm{Y} 2$ & $-0,104$ & & $-0,104$ \\
$\mathrm{X} 2 \rightarrow \mathrm{Y} 1$ & 0,428 & & 0,428 \\
$\mathrm{X} 2 \rightarrow \mathrm{Y} 2$ & $-0,082$ & $-0,175$ & $-0,257$ \\
$\mathrm{X} 3 \rightarrow \mathrm{Y} 1$ & 0,280 & & 0,280 \\
$\mathrm{X} 3 \rightarrow \mathrm{Y} 2$ & $-0,406$ & $-0,115$ & $-0,521$ \\
$\mathrm{Y} \longrightarrow \mathrm{Y} 2$ & $-0,410$ & & $-0,410$ \\
\hline
\end{tabular}

Sumber: Data diolah, 2021

Berdasarkan hasil pengujian diketahui bahwa nilai pengaruh langsung investasi (X1) terhadap pertumbuhan ekonomi (Y1) sebesar 0,180. Tidak ada pengaruh tidak langsung diantara variabel tersebut, sehingga pengaruh totalnya tetap sebesar 0,180 . Pengaruh langsung pengeluaran pemerintah (X2) terhadap pertumbuhan ekonomi (Y1) sebesar 0,428. Tidak ada pengaruh tidak langsung diantara variabel tersebut, sehingga pengaruh totalnya tetap sebesar 0,428. Pengaruh langsung tenaga kerja (X3) terhadap pertumbuhan ekonomi (Y1) sebesar 0,280. Tidak ada pengaruh tidak langsung diantara variabel tersebut, sehingga pengaruh totalnya tetap sebesar 0,280 .

Tidak ada nilai pengaruh tidak langsung investasi (X1) dan tingkat kemiskinan (Y2) melalui pertumbuhan ekonomi (Y1), karena variabel investasi (X1) berpengaruh tidak signifikan terhadap pertumbuhan ekonomi (Y1) sehingga nilainya tetap -0.104. Terdapat pengaruh tidak langsung pengeluaran pemerintah (X2) dan tingkat kemiskinan (Y2) melalui pertumbuhan ekonomi (Y1) dengan nilai tidak langsung sebesar $-0,175$ dan nilai pengaruh tidak langsung tenaga kerja (X3) dan tingkat kemiskinan (Y2) melalui pertumbuhan ekonomi (Y1) sebesar -0,115.

Berdasarkan hasil analisis diperoleh variabel investasi berpengaruh tidak signifikan terhadap pertumbuhan ekonomi di Provinsi Bali. Investasi berpengaruh tidak signifikan pada penelitian ini berarti investasi baik PMA dan PMDN memiliki pengaruh arah yang positif terhadap pertumbuhan ekonomi tetapi pada saat ini belum mampu meningkatkan atau berkontribusi terhadap pertumbuhan ekonomi. Hasil penelitian ini sesuai dengan penelitian yang dilakukan oleh Windayana (2020) dan Mulyaputri (2018) bahwa investasi memiliki pengaruh tidak signifikan terhadap pertumbuhan ekonomi. Hal ini mengindikasikan bahwa investasi belum mampu secara maksimal mendorong pertumbuhan ekonomi secara maksimal melalui nilai Produk Domestik Regional Bruto (PDRB). Jika investasi yang ada mampu menaikkan pertumbuhan ekonomi, maka investasi dapat menjadi tolok ukur keberhasilan pembangunan ekonomi suatu daerah karena dapat menyerap tenaga kerja yang pada akhirnya melalui investasi berdampak pada peningkatan pendapatan masyarakat. Hal disebabkan karena semakin besar investasi maka akan menyebabkan pertumbuhan ekonomi meningkat.

Terdapatnya perbedaan hasil penelitian dengan teori yang sudah ada dapat disebabkan oleh pengelolaan investasi yang masuk ke setiap kabupaten/kota di Provinsi Bali belum memberikan efek multiplier pada semua sektor di daerah yang bersangkutan. Untuk meningkatkan investasi di kabupaten/kota Provinsi Bali beberapa upaya yang dapat dilakukan yaitu, meningkatkan pelayanan publik agar mempermudah investor untuk berinvestasi di Bali, perlunya peningkatan infrastuktur seperti pembangunan jalan tol, jembatan, pelabuhan, bandara untuk memperlancar konektivitas jalur logistik,

Pengaruh Investasi, Pengeluaran Pemerintah, Tenaga Kerja Terhadap Pertumbuhan Ekonomi dan Tingkat Kemiskinan di Provinsi Bali, 
digitalisasi untuk meningkatkan efisiensi serta optimalisasi aset sumber daya dan yang terakhir pengembangan kualitas dan kuantitas SDM seperti pembangunan fasilitas pendidikan dan kesehatan agar masyarakat seiring waktu ikut serta mendukung dalam meningkatkan pertumbuhan ekonomi melalui produktivitas yang tinggi.

Berdasarkan hasil analisis diperoleh variabel pengeluaran pemerintah berpengaruh positif dan signifikan terhadap pertumbuhan ekonomi di Provinsi Bali. Artinya dengan semakin tinggi pengeluaran pemerintah maka pertumbuhan ekonomi akan semakin meningkat, karena pengeluaran pemerintah merupakan faktor penting dalam meningkatkan pertumbuhan ekonomi. Pengeluaran pemerintah sangat diperlukan oleh masing-masing daerah untuk dikelola dan dimanfaatkan seoptimal mungkin sesuai dengan potensi daerah tersebut. Keterkaitan pengeluaran pemerintah terhadap pertumbuhan ekonomi dapat dilihat pada model Rostow \& Musgrave (Guritno, 2003) yang menghubungkan perkembangan pengeluaran pemerintah dengan tahap-tahap pembangunan ekonomi. Tahap awal perkembangan ekonomi, dimana investasi pemerintah terhadap total investasi besar sebab tahap ini pemerintah harus menyediakan prasarana seperti pendidikan, kesehatan, transportasi dan sebagainya. Tahap menengah pembangunan ekonomi, peran pemerintah masih diperlukan tetapi peranan investasi swasta sudah semakin membesar.

Hasil penelitian ini sejalan dengan penelitian yang dilakukan oleh Maharani \& Isnowati (2014) memperoleh hasil pengeluaran pemerintah bertanda positif, ini menunjukkan bahwa adanya kenaikan pengeluaran pemerintah, maka akan menaikkan tingkat pertumbuhan ekonomi di Jawa Tengah. Hal ini mengindikasikan bahwa setelah otonomi daerah peran pengeluaran pemerintah daerah sangat diperlukan untuk tumbuh serta berkembangnya kemampuan suatu daerah. Sesuai dengan teori tentunya apabila pemerintah mengoptimalkan pengeluaran pemerintah apalagi untuk kegiatan-kegiatan yang produktif maka akan berdampak pada meningkatnya pertumbuhan ekonomi di daerah (Kaharudin, 2019).

Berdasarkan hasil analisis diperoleh variabel tenaga kerja berpengaruh positif dan signifikan terhadap pertumbuhan ekonomi di Provinsi Bali. Hasil positif dan signifikan pada penelitian ini artinya bahwa semakin besar jumlah tenaga kerja maka akan meningkatkan output yang dihasilkan sehingga mampu meningkatkan pertumbuhan ekonomi (PDRB perkapita) di kabupaten/kota Provinsi Bali. Hasil penelitian ini sesuai dengan pertumbuhan Solow-Swan yang menyatakan bahwa tenaga kerja merupakan salah satu faktor untuk meningkatkan pertumbuhan ekonomi. Dalam teori tersebut Solow-Swan yang menyatakan bahwa faktor tenaga kerja mampu meningkatkan pertumbuhan ekonomi melalui produktivitas yang dihasilkan oleh tenaga kerja tersebut

Hal ini sejalan dengan penelitian yang dilakukan oleh Buana dkk., (2019) yang mengatakan jika tenaga kerja berpengaruh signifikan terhadap pertumbuhan ekonomi. Tenaga kerja merupakan faktor yang paling dominan memberikan kontribusi bagi pertumbuhan ekonomi di pulau Jawa. Sebesar $60 \%$ penduduk Indonesia mendiami pulau Jawa. Harus ada kebijakan menyeluruh mulai dari berapa jumlah industri di daerah itu, berapa jumlah kemampuan industri menyerap tenaga kerja sampai dengan bagaimana dunia pendidikan mampu menyediakan kebutuhan tenaga kerja yang dibutuhkan industri. Pemda hendaknya fokus pada kebijaksanaan bagaimana dapat mengembangkan skill pekerja agar sesuai dengan pekerjaan yang ditekuninya.

Berdasarkan hasil analisis diperoleh variabel investasi berpengaruh tidak signifikan terhadap tingkat kemiskinan di kabupaten/kota Provinsi Bali. Hasil tidak signifikan pada penelitian ini berarti tidak sejalan dengan hipotesis penelitian yang menyatakan bahwa investasi berpengaruh negatif dan signifikan terhadap tingkat kemiskinan di kabupaten/kota Provinsi Bali. Artinya bahwa investasi baik PMA dan PMDN masih belum merata dan tidak menyentuh masyarakat miskin yang ada di kabupaten/kota Provinsi Bali. Menurut Adam Smith investasi yang dilakukan karena para pemilik modal

Pengaruh Investasi, Pengeluaran Pemerintah, Tenaga Kerja Terhadap Pertumbuhan Ekonomi dan Tingkat 
mengharapkan untung dan harapan masa depan keuntungan bergantung pada iklim investasi pada hari ini dan keuntungan nyata.

Hasil penelitian ini sesuai dengan yang dikemukakan oleh Mustamin dkk., (2015) yang menyatakan bahwa adanya hasil yang tidak berpengaruh antara investasi dengan kemiskinan diduga disebabkan oleh kebanyakan investasi yang ada hanya dilakukan kaum menengah keatas dan itu hanya berdampak pada kehidupan mereka masing-masing dan tidak memberikan pengaruh terhadap kehidupan pada penduduk miskin. Penelitian oleh Dwiazhari (2020) menyatakan bahwa investasi berpengaruh negatif namun tidak signifikan terhadap pengentasan kemiskinan. Penyebab tidak signifikansi disebabkan oleh kurangnya daya saing antar wilayah, dimana investasi masih berpusat di wilayah sentral perekonomian dan perindustrian saja. Terlebih lagi masing-masing wilayah memiliki anggaran pembangunan yang berbeda-beda dengan fokus berbeda-beda maka dari itu investasi kurang signifikan dalam pengentasan masalah kemiskinan. Seperti halnya di kabupaten/kota Provinsi Bali perkembangan investasi hanya berpusat di wilayah Bali Selatan, hal ini tidak terlepas dari pengaruh sektor pariwisata yang menjadi tulang punggung perekonomian di daerah tersebut. Hanya daerah-daerah yang mendapatkan profit menjanjikan yang dilirik oleh investor swasta maupun asing, sehingga peningkatan investasi belum dirasakan merata terutama di wilayah Bali Utara, Barat dan Timur. Realisasi penanaman investasi yang tinggi belum menjamin penurunan angka kemiskinan di Provinsi Bali, apabila investasi dilakukan pada satu sektor atau daerah tertentu saja maka akan berdampak pada ketimpangan dan kecemberuan sosial antar daerah. Sehingga perlu mengupayakan peningkatan dan pemerataan investasi dengan cara yaitu, menciptakan iklim investasi yang baik dengan mewujudkan rasa aman bagi para investor untuk menanamkan modalnya, memfokuskan investasi untuk diarahkan ke Bali Utara, Barat dan Timur dengan peningkatan sarana dan prasarana penunjang, serta mempermudah investor untuk mengurus perizinan usahanya. Dengan adanya peningkatan investasi menyebabkan semakin banyaknya terbuka lapangan kerja serta penyerapan tenaga kerja dan pada gilirannya berdampak pada peningkatan taraf hidup masyarakat.

Berdasarkan hasil analisis yang telah dilakukan, diperoleh bahwa pengeluaran pemerintah berpengaruh tidak signifikan terhadap tingkat kemiskinan di kabupaten/kota Provinsi Bali. Artinya bahwa pengeluaran pemerintah belum mampu memberikan dampak dalam pengurangan jumlah penduduk miskin di kabupaten/kota Provinsi Bali. Hal ini tidak sejalan dengan Teori Adolf Wagner yang menyatakan bahwa dalam suatu perkonomian apabila pendapatan perkapita meningkat maka secara relatif pengeluaran pemerintah akan meningkat terutama disebabkan karena pemerintah harus mengatur hubungan yang timbul dalam masyarakat seperti, pendidikan, kesehatan, rekreasi, hukum dan sebagainya.

Menurut penelitian yang dilakukan Ramdani (2015) kemungkinan besar yang menyebabkan pengeluaran pemerintah tidak signifikan karena pengeluaran pemerintah untuk pengentasan kemiskinan belum efektif dan perlu waktu lebih panjang agar penyerapannya menjadi efektif. Salah satu cara agar pengeluaran pemerintah lebih efektif dengan cara meningkatkan porsinya untuk pengentasan kemiskinan sehingga diharapkan dampaknya dapat lebih cepat dirasakan. Pemerintah Provinsi Bali dalam upaya pengentasan kemiskinan perlu menentukan pelaksanaan kebijakan untuk mengidentifikasi kebijakan mana yang dibutuhkan oleh suatu daerah untuk meningkatkan kesejahteraan dan yang lebih mempengaruhi penurunan kemiskinan melalui pengeluaran pemerintah pada sektor-sektor seperti pendidikan, kesehatan, infrastruktur, subsidi, perumahan, teknologi dan sebagainya. Serta program pemberdayaan masyarakat harus ditunjukkan kepada masyarakat miskin agar lebih produktif sehingga memiliki penghasilan yang lebih baik. Dengan semakin besar dan tepatnya pengeluaran pemerintah yang dikeluarkan dapat menurunkan jumlah penduduk miskin yang ada di Provinsi Bali.

Pengaruh Investasi, Pengeluaran Pemerintah, Tenaga Kerja Terhadap Pertumbuhan Ekonomi dan Tingkat 
Berdasarkan hasil analisis diperoleh bahwa tenaga kerja berpengaruh negatif dan signifikan terhadap tingkat kemiskinan di kabupaten/kota Provinsi Bali. Artinya bahwa setiap kenaikan jumlah tenaga kerja mampu mengurangi jumlah penduduk miskin yang ada di kabupaten/kota Provinsi Bali. Hal ini sejalan dengan penelitian yang dilakukan oleh Ratih dkk., (2017) dan Prasetyawan dkk., (2017) mendapatkan bahwa tenaga kerja berpengaruh negatif terhadap tingkat kemiskinan, artinya semakin tinggi tenaga kerja maka tingkat kemiskinan akan semakin menurun.

Sumber daya manusia dipandang sebagai unsur pendukung utama yang sangat menentukan dalam proses pembangunan selain sumber daya alam dan teknologi. Pentingnya pelatihan keterampilan dapat meningkatkan kualitas tenaga kerja yang berdampak pada peningkatan produktivitas tenaga kerja. Hal ini menjelaskan bahwa peranan pendidikan pada ranah ketenagakerjaan mampu mendorong tenaga kerja untuk mencapai pendapatan lebih untuk memenuhi kebutuhan hidup dan tercapainya kesejahteraan masyarakat.

Berdasarkan hasil analisis diperoleh bahwa pertumbuhan ekonomi berpengaruh negatif dan signifikan terhadap tingkat kemiskinan di kabupaten/kota Provinsi Bali. Hal ini sejalan dengan hipotesis bahwa meningkatnya pertumbuhan ekonomi akan menurunkan presentase angka kemiskinan. Menurut Simon Kuznet pertumbuhan dan kemiskinan mempunyai korelasi yang kuat, karena pada tahap awal proses pembangunan, tingkat kemiskinan cenderung meningkat dan pada saat mendati tahap akhir pembangunan, jumlah orang miskin berangsur-angsur berkurang (Tambunan, 2014). Pertumbuhan ekonomi memiliki pengaruh negatif dan signifikan terhadap tingkat kemiskinan. Artinya pertumbuhan ekonomi merupakan syarat bagi pengurangan kemiskinan. Hasil ini sesuai dengan penelitian yang dilakukan oleh Paramita (2015) dan Hambarsari \& Inggit (2016) yang menyatakan bahwa pertumbuhan ekonomi memiliki pengaruh negatif dan signifikan terhadap tingkat kemiskinan. Pertumbuhan ekonomi yang ada di kabupaten/kota Provinsi Bali relatif stabil dan berdampak pada penurunan jumlah penduduk miskin. Pertumbuhan ekonomi yang di proyeksikan dari PDRB perkapita telah dapat menurunkan tingkat kemiskinan yang ada di kabupaten/kota Provinsi Bali. Walaupun jumlah penduduk miskin masih banyak tersebar di pedesaan, namun secara umum pertumbuhan PDRB perkapita sudah cukup baik dalam pengentasan kemiskinan.

Berdasarkan hasil analisis diperoleh bahwa pertumbuhan ekonomi memediasi secara penuh pengeluaran pemerintah terhadap tingkat kemiskinan di kabupaten/kota Provinsi Bali, karena pada pengujian pengaruh langsung didapatkan hasil variabel pengeluaran pemerintah berpengaruh signifikan terhadap pertumbuhan ekonomi sedangkan pengeluaran pemerintah berpengaruh tidak signifikan terhadap tingkat kemiskinan. Hasil penelitian ini sesuai dengan penelitian yang dilakukan oleh Amalia dkk., (2015) yang menyatakan bahwa pengeluaran pemerintah memiliki efek langsung dan tidak langsung terhadap kemiskinan. Efek langsung muncul dalam bentuk manfaat yang diterima dari pengeluaran pada program kerja dan kesejahteraan. Efek tidak langsung muncul ketika investasi pemerintah di bidang infrastruktur pedesaan, penelitian pertanian, kesehatan dan pendidikan masyarakat pedesaan merangsang pertumbuhan pertanian dan non-pertanian yang mengarah ke pekerjaan yang lebih besar dan kesempatan memperoleh penghasilan bagi masyarakat miskin dan bahan makanan yang lebih murah. Secara teoritis, hubungan antara belanja publik dan kemiskinan berasal dari tiga sumber yaitu pertumbuhan ekonomi, kesempatan kerja dan upah. Peningkatan belanja publik akan meningkatkan permintaan agregat dalam perekonomian. Permintaan terhadap tenaga kerja sebagai akibat dari meningkatnya permintaan agregat menaikkan tingkat produktivitas tenaga kerja.

Berdasarkan hasil analisis diperoleh bahwa pertumbuhan ekonomi memediasi secara parsial variabel tenaga kerja terhadap tingkat kemiskinan di kabupaten/kota Provinsi Bali, karena pada pengujian pengaruh langsung didapatkan hasil variabel tenaga kerja berpengaruh signifikan terhadap pertumbuhan ekonomi dan pertumbuhan ekonomi berpengaruh signifikan terhadap tingkat kemiskinan.

Pengaruh Investasi, Pengeluaran Pemerintah, Tenaga Kerja Terhadap Pertumbuhan Ekonomi dan Tingkat 
Hasil penelitian ini sesuai dengan penelitian yang dilakukan oleh Prasetyawan dkk., (2017) yang memperoleh hasil terdapat pengaruh secara tidak langsung tenaga kerja mempunyai kontribusi menurunkan tingkat kemiskinan melalui pertumbuhan ekonomi. Dengan terserapnya tenaga kerja memungkinkan masyarakat untuk mencapai produktivitas yang lebih tinggi, yang akan berdampak pada kenaikan pertumbuhan ekonomi di suatu daerah. Semakin banyak tenaga kerja yang terserap di lapangan maka peluang mereka untuk mendapat penghasilan guna memenuhi kebutuhan hidup mereka lebih besar sehingga semakin besar pula peluang mereka terlepas dari permasalahan kemiskinan.

\section{SIMPULAN DAN SARAN}

Berdasarkan hasil pembahasan maka dapat disimpulkan bahwa investasi berpengaruh positif dan tidak signifikan terhadap pertumbuhan ekonomi di Provinsi Bali; pengeluaran pemerintah dan tenaga kerja secara langsung berpengaruh positif dan signifikan terhadap pertumbuhan ekonomi di Provinsi Bali; investasi dan pengeluaran pemerintah secara langsung berpengaruh negatif dan tidak signifikan terhadap tingkat kemiskinan di Provinsi Bali; tenaga kerja dan pertumbuhan ekonomi secara langsung berpengaruh negatif dan signifikan terhadap tingkat kemiskinan di Provinsi Bali; Investasi tidak berpengaruh secara tidak langsung terhadap tingkat kemiskinan melalui pertumbuhan ekonomi, sedangkan pengeluaran pemerintah dan tenaga kerja berpengaruh secara tidak langsung terhadap tingkat kemiskinan melalui pertumbuhan ekonomi di Provinsi Bali.

Berdasarkan hasil penelitian dan simpulan diatas, maka dapat diajukan saran dalam pengembangan investasi yang dilakukan harus ditujukkan pada sektor-sektor yang memang dibutuhkan dan dikembangkan pada suatu daerah. Hal ini bertujuan untuk tercapainya investasi yang efisien sehingga manfaat yang diberikan dapat dirasakan bagi masyarakat dan meningkatkan kontribusi PDRB terhadap pertumbuhan ekonomi di Provinsi Bali. Disamping itu, untuk meningkatkan investasi perlu adanya peningkatan kualitas SDM melalui peningkatan kualitas pendidikan dan kesehatan yang akan menciptakan kualitas sumber daya manusia yang berkualitas. Pemerintah daerah diharapkan lebih memperhatikan pengeluaran pemerintah terkait program-program pengentasan kemiskinan agar program yang dilaksanakan dapat tepat sasaran, tepat mutu dan tepat waktu sehingga memberikan manfaat terhadap penurunan jumlah penduduk miskin. Selain itu, pengeluaran pemerintah lebih diarahkan pada pembangunan infrastruktur publik sesuai dengan kebutuhan daerah dalam mengembangkan potensi daerahnya. Sehingga tujuan dari pengeluaran pemerintah untuk mensejahaterahkan masyarakat dan menurunkan angka kemiskinan dapat berkontribusi terhadap pertumbuhan ekonomi di Provinsi Bali. Pemerintah daerah diharapkan dapat meningkatkan produktifitas tenaga kerja melalui pendidikan dan pelatihan tenaga kerja sehingga terciptanya tenaga kerja yang berkualitas dapat terserap sesuai dengan keahlian dan kemampuannya. Dengan terserapnya tenaga kerja diharapkan dapat meningkatkan pendapatan perkapita dan menambah output dalam perekonomian.

\section{REFERENSI}

Almfraji, Alm safir, Liu Ya o. (2014). Economic Growth and Foreign DirectInvestment Inflows: The Case of Qatar. Socialand Behavioral Sciences, 10(9), 1040 - 1045

Amalia, R., \& Rahman Razak, A. (2015). Pengaruh Pengeluaran Pemerintah terhadap Kemiskinan di Provinsi Sula wesi Barat. JurnalAnalisis, 4(2), 183-189

Arsyad, Lincolin. (2010). Ekonomi Pembangunan, Edisikelima. Yogyakarta: UPP STIM YKPM

Balisacan, A.,Pernia, E. M., \& Asra, A. (2003). Revisiting Growth and Poverty in Indonesia. What do Subnational Data Show?. Bulletin of Indonesia Economic Studies, 39(3), 329-351.

Bibi, Sa mi. 2006. Growth With Equity is Better For the Poor. Working Paper 06-40. Centre Interuniversitaire Sur

Pengaruh Investasi, Pengeluaran Pemerintah, Tenaga Kerja Terhadap Pertumbuhan Ekonomi dan Tingkat

Kemiskinan di Provinsi Bali,

Lufi Supratiyoningsih dan Ni Nyoman Yuliarmi 
Le Risque

Buana, A. L., Sa ragih, H. J. R., \& Aritonang, S. (2019). Pengaruh Pengeluaran Pemerintah, Investasi Pemerintah, Investasi Swasta dan Tenaga Kerja Terhadap Pertumbuhan Ekonomi Di Pulau Jawa Tahun 2011 2015. Ekonomi Pertahanan,4(2).1-10

De Fina, R. H. (2002). The Impact Of Unemployment On Alternatif Poverty Measures. Internasional Journal of Economic, 1 (2), 1-20.

Dwiazhari, D. (2020). Analisis Faktor-Faktor Yang Mempengaruhi Tingkat Kemiskinan Di Provinsi Jawa Timur. Jurnal Ilmiah Mahasiswa FEB, 8(2).23-40

Ginting, A.M. and Dewi, G.P., (2013). Pengaruh Pertumbuhan Ekonomi dan Pertumbuhan Sektor Keuangan terha dap Pengurangan Kemiskinan di Indonesia. Jumal Ekonomi \& Kebijakan Publik, 4(2), 117-130.

Guritno, Mangkoesoebroto. (2001). Ekonomi publik. Yogyakarta : BPFE

Hambarsari, D. P \& Inggit, K. (2016). Ana lisis Penga ruh pertumbuhan ekonomi, pertumbuhan penduduk dan infla si terhadap tingkat kemiskinan di ja wa Timur Ta hun 2004-2014. Jurnal ekonomi dan Bisnis, 1(2), 257-282

Ishengoma, Esther K. and Robert Kappel. (2006). Economic Growth a nd Poverty:DoesFormalisation on Informal Enterprises Matter. GIGA Working Papers, GIGA-WP-20

Jonnadi, A., Amar, S. and Aimon, H., (2012). Analisis pertumbuhan ekonomi dan kemiskinan di indonesia. Jumal Kajian Ekonomi, 1(1), 140-164

Kaharudin, R., Kumenaung, A. G., \& Niode, A. O. (2019). Pengaruh Pengeluaran Pemerintah Terhadap Pertumbuhan Ekonomi, Pengangguran Dan Kemiskinan (Studi Kasus Pada Kota Manado Tahun 20012017). Jurnal Berkala Ilmiah Efisiensi, 19(04).1-10.

Maharani, K., \& Isnowati, S. (2014). Kajian investasi, pengeluaran pemerintah, tenaga kerja dan keterbukaan ekonomi terhadap pertumbuhan ekonomidi Propinsi Ja wa Tengah. Jurnal Bisnis dan Ekonomi, 21(1). 114

Mankiw, N. Gregory. (2003). Teori Makro Ekonomi, Edisi Kelima, Penerbit Erla ngga, Jakarta

Mulya putri, I. G. A. K., \& Kartika, I. N. (2020). Pengaruh Investasi Swa sta Dan Tingkat Pendidikan Terhadap Penyerapan Tenaga Kerja Dan Pertumbuhan Ekonomi Kabupaten/Kota Di Provinsi Bali. E-Jurnal Ekonomi dan Bisnis Universitas Udayana, 9(4), 719-962.

Mustamin, S. W., \& Agussa lim, S. U. N. (2015). Pengaruh Variabel Ekonomi Makro Terhadap Kemiskinan Di Kota Makassar Provinsi Sulawesi Sela tan. JurnalAnalisis, 4(2), 165-173.

Perry, G. E., Lopez, J. H., Maloney, W. F., Aria s, O., \& Servén, L. (2006). Poverty reduction and growth: Virtuous and vicious circles. The World Bank

Pratama, N. R. N. S., \& Utama, M. S. (2019). Pengaruh Pengeluaran Pemerintah dan Investasi Temadap Pertumbuhan Ekonomi dan Tingkat Kemiskinan di Kabupaten/Kota Provinsi Bali. E-JurnalEkonomidan Bisnis Universitas Udayana,8(7), 651-680.

Prasetyawan, D., Hanim, A., \& Yuliati, L. (2017). Analisis Pengaruh Investasi dan Tenaga Kerja Tehadap Pertumbuhan Ekonomi Serta Hubungannya Terhadap Kemiskinan di Provinsi Jawa Timur. Jurnal Ekuilibrium, 1(1), 45-50

Purna ma, N. P. A. M. (2016). Faktor-faktor yang mempen garuhi Kemiskinan di Provinsi Bali. Jurnal PIRAMIDA, 12(1), 101-110.

Putra dan Sri Budhi. (2015). Efektivitas dan Dampak Program Na sional Pemberdayaan Masyarakat Mandiri Perdesaan (PPnm-Mpd) Terhadap Peningkatan Kesejahteraan dan Kesempatan Kerja Rumah Tangga di Kecamatan Abiansemal Kabupaten Badung. E-Jurnal EKonomi dan Bisnis Universitas Udayana, 4 (3), 183-196

Putra, W., (2017). Dampak Pengeluaran Pemerintah Terhadap Pertumbuhan Ekonomi dan Indeks Pembangunan Manusia di Perbatasan Indonesia. Jurnal Ekonomi Bisnis dan Kewirausahaan (JEBIK), 6(2), 120-138

Ramdani, M. (2015). Determinan kemiskinan di Indonesia tahun 1982-2012. Economics Development Analysis Journal, 4(1), 58-64

Ratih, G.A., Uta ma, M.S. \& Yasa, I.N.M., (2017). Penga ruh Investasi, Pengeluaran Pemerintah, Tenaga Kerja Terha dap Produk Domestik Regional Bruto dan Tingkat Kemiskinan pada Wila yah Sarbagita di Provinsi Ba li. E-jurnal ekonomi dan bisnis universitas udayana, 6(2017), 29-54

Risnawati, R., (2019). Pengaruh Investasi, Tenaga Kerja dan Tingkat Inflasi Terhadap Pertumbuhan Ekonomi Di Provinsi Sula wesi Ba rat. CESJ: Center Of Economic Students Journal, 2(3), 135-143.

Sukirno, Sadono. (2011). Makro Ekonomi Teori Pengantar Edisi Ketiga. Rajawali Pers, Jakarta

Todaro, Michael. P. (2000). Pembangunan Ekonomi di Dunia Ketiga. EdisiKetujuh, Terjemahan Haris Munandar. Jakarta : Penerbit Erlangga

Windayana, I. B. A. B., \& Darsana, I. B. (2020). Pengaruh Tingkat Pendidikan, Umk, Investasi Terhadap Penyerapan Tenaga Kerja Dan Pertumbuhan Ekonomi, Kabupaten/Kota Di Provinsi Bali. E-Jurnal

Pengaruh Investasi, Pengeluaran Pemerintah, Tenaga Kerja Terhadap Pertumbuhan Ekonomi dan Tingkat Kemiskinan di Provinsi Bali, 
Ekonomi dan Bisnis Universitas Udayana, 2(1), 57-72

Yuliarmi, N. N. (2014). Keberda yaan Industri Kerajinan Rumah Tangga Untuk Pengentasan Kemiskinan Di Provinsi Bali (Ditinjau Da ri Aspek Modal SosialDan Peran Lembaga Adat). Jurnal PIRAMIDA, 10(1), hal. $19-28$

Pengaruh Investasi, Pengeluaran Pemerintah, Tenaga Kerja Terhadap Pertumbuhan Ekonomi dan Tingkat 